\title{
Assessment of Land Use/Land Cover and Its Dynamic Using Geospatial Techniques in Pudukkottai District of Tamil Nadu, India
}

\author{
Yuvaraj R. M. \\ Department of Geography, Queen Mary's College, Chennai, India
}

Received April 14, 2020; Revised May 1, 2020; Accepted June 16, 2020

\section{Cite This Paper in the following Citation Styles}

(a): [1] Yuvaraj R. M. , "Assessment of Land Use/Land Cover and Its Dynamic Using Geospatial Techniques in Pudukkottai District of Tamil Nadu, India," Environment and Ecology Research, Vol. 8, No. 4, pp. 85 - 99, 2020. DOI: 10.13189/eer.2020.080401.

(b): Yuvaraj R. M. (2020). Assessment of Land Use/Land Cover and Its Dynamic Using Geospatial Techniques in Pudukkottai District of Tamil Nadu, India. Environment and Ecology Research, 8(4), 85 - 99. DOI: 10.13189/eer.2020.080401.

Copyright $\bigcirc 2020$ by authors, all rights reserved. Authors agree that this article remains permanently open access under the terms of the Creative Commons Attribution License 4.0 International License

\begin{abstract}
Identifying the land use/land cover pattern and its changes plays a considerable role in assessing the impact of man's activity towards natural ecosystem. This study focuses on the agrarian land use change over the study region of Pudukkottai district which is situated in the semi-arid region of Tamil Nadu, India. Agriculture is one of the significant sources of income for the economy of the country and most of the people engaged in agriculture and its related activity in the study area. It needs deep monitoring of the changes in the agricultural land use at time to time to prevent mismanagement and poverty among the people of the Pudukkottai district. The present research observes the land use change of agriculture for two periods i.e. $2005-2010$ and $2010-$ 2015 using Landsat images from USGS. To execute the land use characteristics, the study adopted four indicators they are net total area of change, annual area of change, annual rate of change and dynamic degree. The study concludes that maximum changes happened during $2010-$ 2015 and minimum changes happened during $2005-2015$. Maximum of agricultural land has changed into wasteland followed by built-up land and wetland.
\end{abstract}

Keywords Agriculture, Land Use/Land Cover Change, Agricultural Land Use, Pudukkottai District

\section{Introduction}

The most significant natural resources in the world is Land which represents water, soil, vegetation and fauna involving the entire ecosystem on which human activities are based. The demand for land has proportionally increasing with the population growth. Changes in the Land use/Land cover have significant consequences on environment not only at local or regional but also on global level. The major consequences at the regional and global level are loss of biodiversity, changes in global radiation, modification in biogeochemical cycles and disturbance of hydrological cycle (Lambin et al., 2003) (Steffen et al., 2006) (lambin \& Geist, 2008) (Jensen 2005) (Lawler Joshua J. et al., 2014) (Mooney Harold A. et al., 2013) (Wulder Machael. A., 2008) (Zhu \& curtis 2014). Land use/land cover change (LULCC) is restricted and place-specific, and jointly these changes add to worldwide environmental change. At the local level changes in the land use/land cover affect watershed runoff, micro-climatic resources, ground water potential, acceleration of land degradation and landscape level biodiversity. Combinations of all these have direct impacts on livelihoods of local communities. Land use and land cover are frequently utilized interchangeably but in reality both terms have various meanings. 'Land cover' means the natural as well as anthropogenic features that can be seen on the global surface. Example for land cover 
is Coniferous forest, built areas, grasslands and so on. On the other hand, 'Land use' portrays activities that take place on the land and represent the current use of property. Example for land use is inhabited homes, shopping malls, reservoirs and so on (NRSA, 1989). Currently, there is numerous ways to observe or detect the changes of land use/land cover over time. In olden days, scientists are entirely depending on the field data and aerial photographs to map LULCC over smaller areas. This method become failure as the size of the area increase because it is very costly and time consuming to overcome this issues scientists are largely depends on remote sensing by the use of satellite imageries considered as an brilliant instrument to study LULCC (Pflugmacher et al., 2012) (Young, 2000) since satellite imagery can cover great geographical extents and have a large temporal coverage. Using of geographical information system (GIS) make it easy and simplification of work in collection, storage and spatial analysis for assessing land use information (Dhinwa et al., 1992). Land use/Land cover change analyze become necessary to study the pattern of change in various regional types and various spatial scales for discussion the mechanism of land use change (Fonji \& Taff 2014). The measurement of land use/land cover and its spatio-temporal processes has turn out to be significant to extend the knowledge of the research plan of the vibrant Planet and to attain future sustainability objectives (Future Earth, 2013). The observing and simulation of land use/land cover change has progressively become a focal point of research for effectual growth of future land management strategies and implementation of sustainable development goals (Kuang et al., 2016) (Wang et al., 2012). The changes in any type of land use mainly depend on the outside forces and the stress build up inside the system (Bisht \& Kothyari, 2001). Changes in the arrangement of land use/land cover can often lead to very unsuitable secondary effects and fragile natural environment (Latham \& Denis, 1980). Evaluation of Spatial and temporal alteration in land use/land cover pattern is an effectual instrument for the evolution of changes happening in land use and the level of environmental degradation. Assessment and close monitoring of land use/land cover change has become necessary for a country like India where decreasing of man - land ratio with increasing population and land degradation, whether the land put to use in a proper way or diverting in an unsustainable. The current study focuses on the monitoring of LULCC at Pudukkottai district which is situated at semi arid region of Tamil Nadu.

\section{Aim}

The focal aim of the research is to analysis Land use/land cover changes in the Pudukkottai district of Tamil Nadu.

\section{Objectives}

- To study the land use/land cover pattern and its changes

- To analyze the net total area of change, annual area of change, annual rate of change and dynamic degree.

- To find the impact of land use/land cover change on the agriculture land.

\section{Data and Methodology}

Landsat 5 TM satellite image for the year 2005 covered over Pudukkottai district has been taken from the USGS (United States Geological survey) earth explorer and Global land cover facility. Similarly, Landsat 5 TM satellite image for the year 2010 and Landsat 8 OLI satellite image for the year 2015 has been considered for the study. The satellite data are interpreted based on the visual interpretation method for the land use land cover pattern for the year 2005, 2010 and 2015 and its changes are identified (Lillesand \& Kiefer, 1994) for the year 2005 - 2010, 2010 - 2015 and overall from 2005 to 2015has carried out utilizing ArcGIS 10.2 software. Spatial statistical investigation for area estimation for every land use/land cover and its changes has been performed. Finally, map layout for every map is completed. Land use/land cover classification (Agriculture, Built-up, Wetlands and wasteland) has been performed based on NRSC (National Remote Sensing Centre) classification system. To better analyze the characteristics of land use/land cover change and expose its rate, the study has taken four indicators. They are net total area of change, annual area of change, annual rate of change, and dynamic degree.

The equation for estimating the annual rate of change $\left(\mathrm{R}_{\mathrm{x}}\right)$ (Ning et al., 2018) of land use type ' $\mathrm{x}$ ' is

$$
\mathrm{R}_{\mathrm{x}}=\left\{\sum_{y}^{n}\left(\frac{\Delta A_{x y}}{A_{x}}\right)\right\} X \frac{1}{p} \times 100 \%
$$

Where, ' $A_{x}$ ' is the area of ' $x$ ' at the beginning state of monitoring, ' $\Delta A_{x y}$ ' is the entire net area of other changed land use types $\mathrm{y}$ from and to $\mathrm{x}, \mathrm{p}$ is the period of measuring the change. ' $\mathrm{R}_{\mathrm{x}}$ ' tells the annual change rate of ' $x$ ' within the study area during ' $p$ '.

The equation for estimating the dynamic degree $\left(D_{x}\right)$ (Ning et al., 2018) of ' $\mathrm{x}$ ' is

$$
\mathrm{D}_{\mathrm{x}}=\left\{\sum_{y}^{n}\left(\frac{\left|\Delta A_{x y}\right|}{A_{t}}\right)\right\} \times \frac{1}{p} \times 100 \%
$$

Where, ' $\mathrm{A}_{\mathrm{t}}$ ' is the total study area, ' $\Delta A_{x y y}$ ' is the total area of absolute value of other changed land use type ' $y$ ' from and to ' $x$ '. ' $D_{x}$ ' tells the change intensity of ' $x$ ' within the study area during ' $p$ '. 


\section{Study Area}

Pudukkottai district has been taken for the study situated in the semi arid region in Tamil Nadu. The entire geographical area of 4663 sq.km with the coast line of 42 $\mathrm{km}$. One among the thirty-two districts of Tamil Nadu is Pudukkottai district which is bounded by Bay of Bengal in the East, District of Thiruchirappalli in the North, district of Thanjavur in the North-east and district of Ramanathapuram in the south and district of Sivagangai in the south. The geographical location of Pudukkottai district is displayed in Fig. 01. The latitude and longitude extension of Pudukkottai District is $9^{0} 50^{\prime} \mathrm{E}$ to $10^{\circ} 40^{\prime} \mathrm{E}$ and $78^{\circ} 25^{\prime} \mathrm{N}$ to $79^{\circ} 15^{\prime} \mathrm{N}$ respectively.

\section{Results and Discussion}

\section{Land use/land cover pattern}

Land use/land cover of Agriculture in the current study composed of cropland, agricultural fallow land and plantation. Built-up land consists of settlement in the rural as well as in the urban, Industries and mining. Wetland consists of tanks, canals, rivers, coastal wetlands, backwaters and water-logged areas. Wasteland which includes scrub land, alkaline land, sandy area and salt pans. Finally, land use/land cover category of Forest.
Land use/land cover pattern of Pudukkottai district for the year 2005, 2010 and 2015 given in the Table 01 and Fig. 02 and Fig. 03.

\section{Agricultural land use}

Total agricultural land of Pudukkottai district for the year 2005 is 334671 ha which is 72 percent of the total geographical area of the study region which is reduced to 327367 ha which represent 70 percent of the entire area during the year 2010. Then, the agricultural land use further reduced to 294229 ha which is 63 percent of the total surface area of Pudukkottai district. Viralimalai block has high agricultural area of 43435 ha which is 9.4 percent of total agricultural area of Pudukkottai district and 77 percent of the total region of Viralimalai block in the year 2005. In the year 2010 Viralimalai block remain maximum agricultural area in the district with 42404 ha but in the year 2015 Aranthangi block become maximum area of agricultural land which is 68 percent of the total region of Aranthangi block which represent 7.9 percent of the total study area. Minimum area of agricultural land use in the year 2005, 2010 and 2015 is Manamelkudi block which has 13508 ha, 13502 ha and 12812 ha represent 2.9 percent, 2.9 percent and 2.75 percent of the total area of the district and 59.40 percent, 59.38 percent and 56.34 percent of the total area of Manamelkudi block.

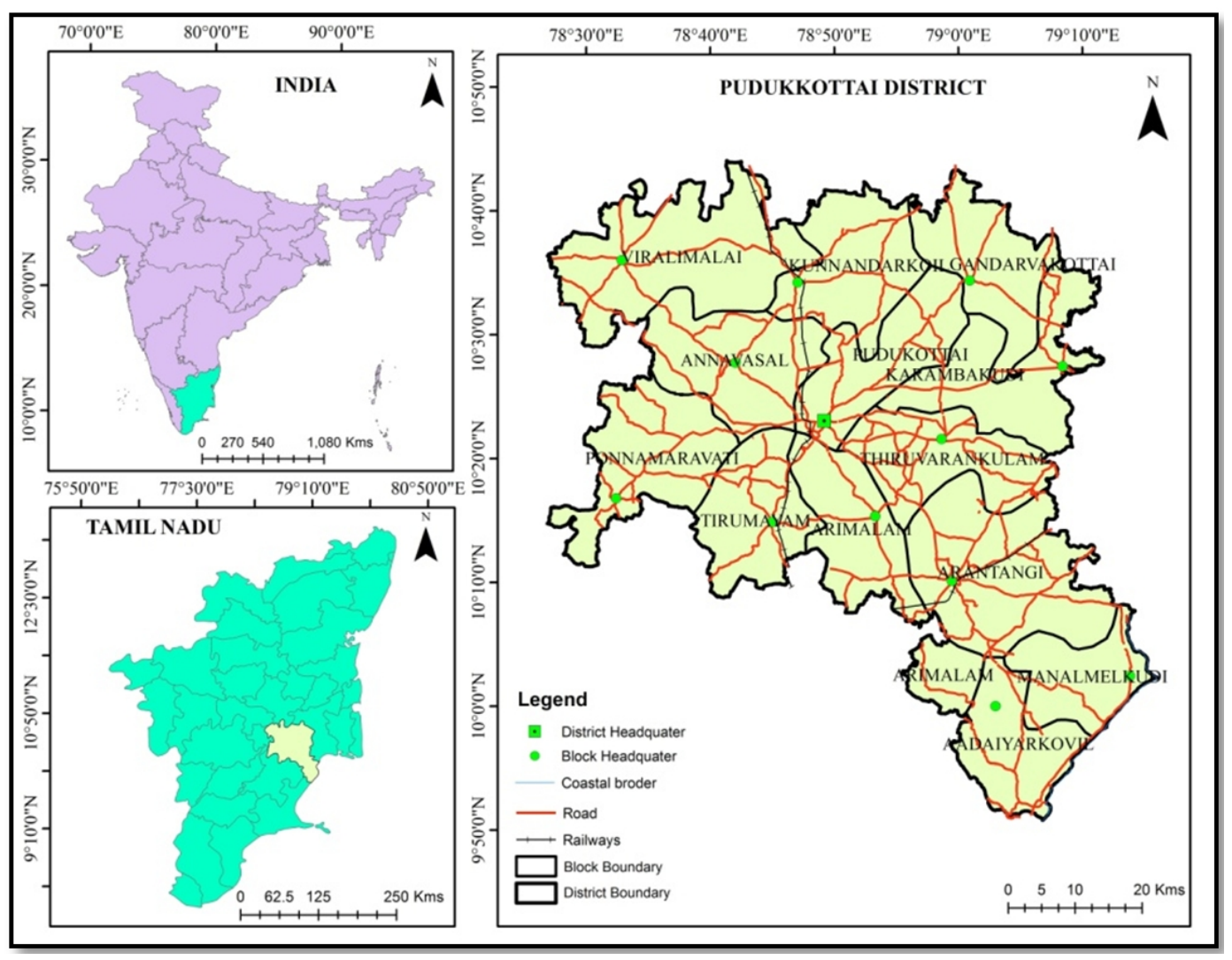

Figure 1. Location of map of Pudukkottai District 


\section{Built- up land use}

Built-up land over Pudukkottai district is 21567 ha in the year 2005 with representation of 4.63 percent of the total geographical region. In the same year, Aranthangi block has maximum built-up land with the total area of 3780 ha which is 0.8 percent of the total geographical region of Pudukkottai district and 7 percent of the total area of Aranthangi block. Minimum built-up land uses in Avudayarkoil block with total area of 196 ha which is 0.04 percent of the total geographical area and 0.76 percent to the total area of Avudayarkoil block. During the year 201022683 ha of land occupied by built-up land which represents 4.8 percent of the total geographical region of Pudukkottai district. In the same year, Aranthangi block and Avudayarkoil block has maximum and minimum built-up land use with the area of 3871 ha and 203 ha which is 0.8 percent and 0.04 percent of the total geographical region of Pudukkottai district and 7.13 percent and 0.78 percent of the total geographical area of Aranthangi and Avudayarkoil block respectively. In the year 2015, built-up land occupies 25421 ha which represent 5.4 percent of the entire geographical area of the study region.

Block wise maximum built-up land is in Aranthangi with 4049 ha and minimum built-up land is in Avudayarkoil block with 208 ha which represents 0.9 percent and 0.04 percent of the total geographical region of the Pudukkottai district and 5.67 percent and 0.80 percent respective to the total region of the Aranthangi and Avudayarkoil blocks.

\section{Wetland land use}

Wetland occupies 66512 ha, 65277 ha and 66459 ha during the year 2005, 2010 and 2015 which represents 14.29 percent, 14.03 percent and 14.28 percent of the total area of Pudukkottai district respectively. Block wise maximum area of wetland occupied in the year 2005, 2010 and 2015 is 9536 ha in Aranthangi block which is 17.56 percent of the total area of the block and 2 percent of the total geographical region of Pudukkottai district and minimum occupied area of wetland is in Gandharvakottai block with 1508 ha which is 4.96 percent of the total area of Gandharvakottai block and 0.32 percent of the total region of Pudukkottai district.

\section{Wasteland}

Total area of wasteland in the Pudukkottai district during the year 2005, 2010 and 2015 is 27147 ha, 33339 ha and 62202 ha respectively which is 5.8 percent, 7.16 percent and 13.36 percent respectively to its total geographical region of Pudukkottai district. Viralimalai block has maximum wasteland in the year 2005 with 4012 ha which is 0.9 percent of the total geographical region of Pudukkottai district and 7.16 percent of the total area of Viralimalai block. Manamelkudi block has minimum wasteland with 449 ha which is 0.10 percent of the total region of Pudukkottai district and 1.97 percent of the total area of Manamelkudi block. In the year 2010 maximum wasteland land use is in Thirumayam block with 5061 ha which is 1.1 percent of the total geographical area of Pudukkottai district and 17.18 percent of the total area of Thirumayam block. Minimum area of wasteland is in Manamelkudi block with 446 ha which is 0.10 percent of the total geographical region of Pudukkottai district and 1.96 percent of the total region of Manamelkudi block. During the year 201562202 ha of land come under the category of wasteland in Pudukkottai district which represent 13.36 percent of the total study area. Maximum area of wasteland occupied in Viralimalai block with 12379 ha which is 22.11 percent of the total area of Viralimalai block and 2.7 percent of the total region of Pudukkottai district. Minimum area of wasteland occupied in Manamelkudi block with 1210 ha which is 0.26 percent of the entire area of Pudukkottai district and 5.32 percent of the total area of Manamelkudi block.

\section{Forest}

Land use/land cover category of Forest remains the same throughout the study period of 15343 ha of the total geographical area of Pudukkottai district with Pudukkottai block accounts largest share of 4603 ha of forest land followed by Arimalam (4589 ha) and lowest share by ponnamaravathi block with 620 ha. 
Table 1. Land use/Land cover pattern of Pudukkottai district (in ha)

\begin{tabular}{|c|c|c|c|c|c|c|c|c|c|c|c|c|c|c|c|}
\hline & LULC & 1 & 2 & 3 & 4 & 5 & 6 & 7 & 8 & 9 & 10 & 11 & 12 & 13 & 14 \\
\hline \multirow{4}{*}{2005} & Agriculture & 15993.49 & 26926.69 & 39059.57 & 22569.90 & 26057.57 & 28864.87 & 25088.04 & 13508.47 & 27544.23 & 20005.75 & 24030.77 & 21486.75 & 43535.02 & 334671.12 \\
\hline & Built-up & 196.94 & 1694.70 & 3780.98 & 1862.92 & 1155.92 & 2058.41 & 886.51 & 994.69 & 1206.81 & 1971.07 & 2174.28 & 1556.36 & 2027.66 & 21567.25 \\
\hline & Wetland & 8668.27 & 5412.25 & 9536.06 & 7049.17 & 1508.30 & 2592.12 & 4609.25 & 7787.80 & 4134.47 & 2559.87 & 2388.14 & 3872.55 & 6393.75 & 66512.00 \\
\hline & Wasteland & 1079.82 & 1883.78 & 1943.18 & 2664.33 & 1687.09 & 1995.35 & 2341.88 & 449.06 & 3846.93 & 1241.36 & 1457.12 & 2545.29 & 4012.26 & 27147.44 \\
\hline \multirow{4}{*}{2010} & Agriculture & 15718.74 & 26239.18 & 38445.21 & 21890.48 & 25790.19 & 28689.91 & 24823.37 & 13502.11 & 27457.22 & 19666.81 & 23919.00 & 18820.74 & 42404.93 & 327367.89 \\
\hline & Built-up & 203.57 & 1820.38 & 3871.83 & 1933.23 & 1216.85 & 2062.64 & 953.31 & 1068.63 & 1206.81 & 2147.03 & 2212.44 & 1706.06 & 2280.43 & 22683.20 \\
\hline & Wetland & 8374.36 & 5412.25 & 9536.06 & 7049.17 & 1508.30 & 2592.12 & 4609.25 & 6847.47 & 4134.47 & 2559.87 & 2388.14 & 3872.55 & 6393.75 & 65277.76 \\
\hline & Wasteland & 1289.16 & 2445.62 & 2465.38 & 3273.44 & 1893.54 & 2166.08 & 2539.75 & 446.17 & 3933.94 & 1404.33 & 1530.73 & 5061.61 & 4889.58 & 33339.30 \\
\hline \multirow{4}{*}{2015} & Agriculture & 15119.13 & 21095.60 & 36883.80 & 18671.90 & 25477.84 & 26890.06 & 22181.30 & 12812.55 & 25332.67 & 17003.23 & 23347.99 & 14886.12 & 34526.94 & 294229.13 \\
\hline & Built-up & 208.54 & 2111.26 & 4049.63 & 2040.66 & 1283.61 & 2281.90 & 1220.53 & 1148.00 & 1545.09 & 2557.19 & 2347.94 & 1974.22 & 2653.40 & 25421.97 \\
\hline & Wetland & 8700.90 & 5412.25 & 9536.06 & 7049.17 & 1508.30 & 2592.12 & 4609.25 & 7702.36 & 4134.47 & 2559.87 & 2388.14 & 3872.55 & 6393.75 & 66459.19 \\
\hline & Wasteland & 1931.81 & 6986.39 & 3848.97 & 6384.58 & 2092.94 & 3746.67 & 4881.94 & 1210.41 & 4424.85 & 3655.78 & 1966.26 & 8692.85 & 12379.38 & 62202.84 \\
\hline
\end{tabular}

$\begin{array}{lcl}\text { Avudayarkoil } & 8 & \text { Manamelkudi } \\ \text { Annavasal } & 9 & \text { Ponnamaravathi } \\ \text { Aranthangi } & 10 & \text { Pudukkottai } \\ \text { Arimalam } & 11 & \text { Thiruvarankulam } \\ \text { Gandharvakottai } & 12 & \text { Thirumayam } \\ \text { Karambakudi } & 13 & \text { Viralimalai } \\ \text { Kunnandarkoil } & 14 & \text { Total }\end{array}$


There is no forest cover in Avudayarkoil, Aranthangi, Gandharvakottai Manamelkudi Thirumayam and Viralimalai block.

\section{Agricultural Land use change}

Land use/land cover change of Pudukkottai district would focus on agricultural land use changes during 2005 - 2010, 2010 - 2015 and 2005 - 2015. Agricultural land use change has been identified with the help of agricultural area change over a period shown in the Table. 02, Fig, 04 and Fig. 05 annual change of agriculture land, annual rate of change and dynamic degree of agricultural land change.

During the period 2005 - 2010 agricultural land 7441 ha has been converted to other land use. 100 ha of other land use/land cover like wasteland and wetland converted to agriculture land. 851 ha, 6363 ha and 226 ha of land has been transformed from agricultural land use to built-up land, waste land and wetland respectively. 35 ha and 65 ha of land converted to agricultural land use from wasteland and wetland respectively. Maximum of 235 ha of agricultural land converted to built-up land in Viralimalai block and minimum of ponnamaravathi block experience nil conversion of agricultural land to built-up land and 4 ha of agrarian land has converted to built-up land experienced in Karambakudi block. Maximum of 2600 ha of agricultural land in Thirumayam block has converted to wasteland followed by Viralimalai block which experience 949 ha of agrarian land converted to wastelands. Manamelkudi block experience nil conversion of agrarian land to wasteland. Arimalam block experience maximum of 104 ha of agrarian land converted to wetlands. Blocks of Annavasal, Aranthangi, Gandharvakottai, Kunnandarkoil, Pudukkottai and Thiruvarankulam experienced no agricultural land converted to wetland. Viralimalai block is the only block where 35 ha of wasteland has been changed to agriculture land whereas remaining blocks experience no conversion of wasteland to agriculture. Manamelkudi block experience maximum of 37 ha of wetlands has converted to agriculture. Remaining block such as Annavasal, Aranthangi, Arimalam, Gandharvakottai, Karambakudi, Kunnandarkoil, Ponnamaravathi, Pudukkottai, Thiruvarankulam, and Thirumayam experiences no conversion of wetland to agrarian given in the Table 02 and Fig. 04. During 2010 to 201534682 ha of land has been transformed from agriculture to various land use/land cover. 2276 ha, 32022 ha and 384 ha of land has converted from agriculture to built-up land, wasteland and wetland respectively. 1431 ha of land has converted from wasteland and wetland to agriculture. Maximum agriculture land of 369 ha in Viralimalai block has converted to built-up land followed by ponnamaravathi block with 326 ha. Avudayarkoil block has minimum conversion of 4 ha of agrarian land to built-up land. Viralimalai block experience maximum conversion of 7605 ha of agrarian land has converted to wasteland followed by Annavasal block and Thirumayam block.

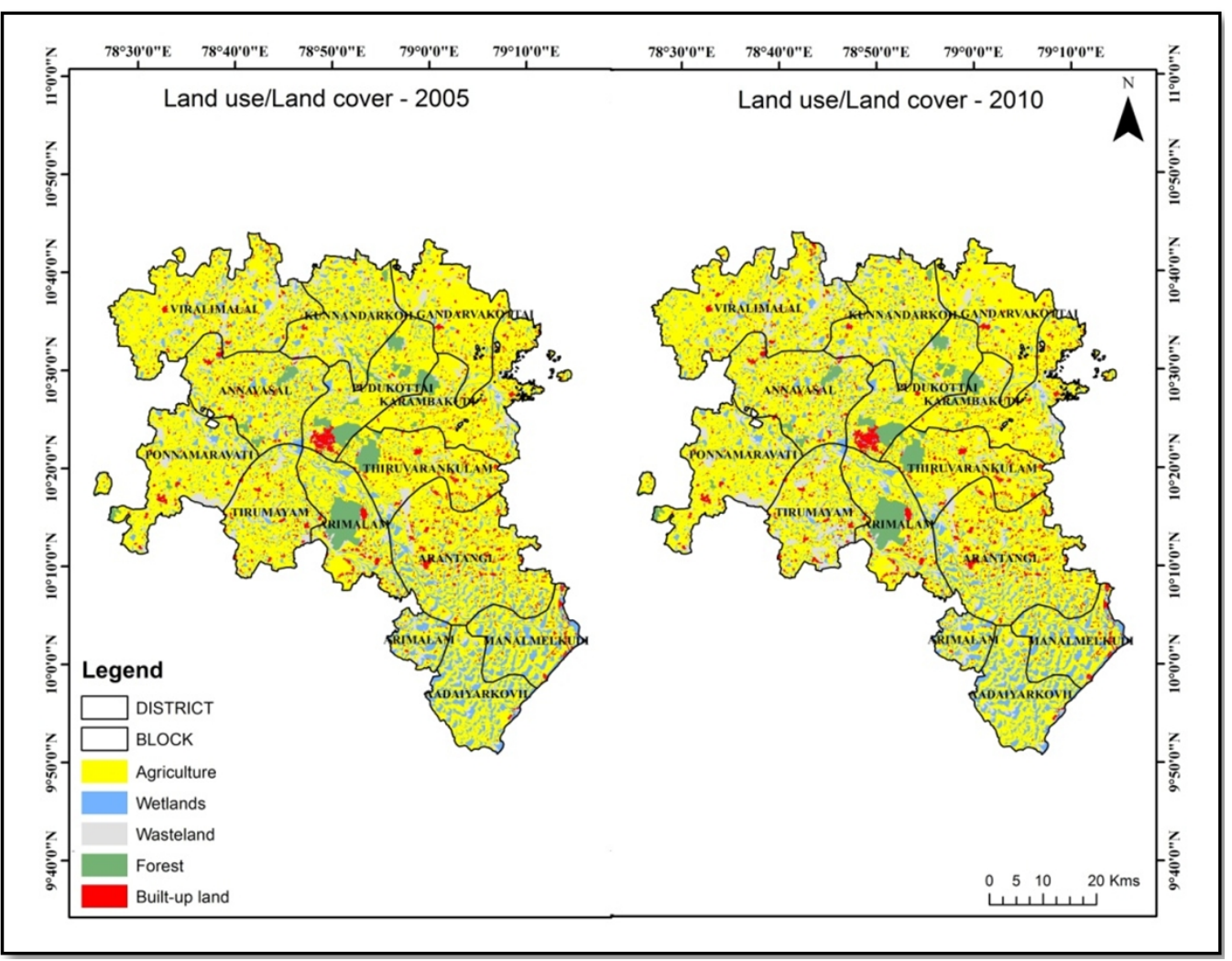

Figure 2. Land use/Land cover -2005 \& 2010 
Minimum transition of agrarian land to wasteland experienced in Avudayarkoil block with 510 ha followed by Manamelkudi block with 618 ha. Thirumayam block has maximum conversion of 119 ha of agriculture land to wetland followed by Avudayarkoil block with the conversion of 91 ha. Annavasal, Aranthangi, Gandharvakottai, Karambakudi and Kunnandarkoil block experience nil transition of agriculture land to wetlands. Gandharvakottai block has maximum conversion of 485 ha of wasteland to agrarian followed by Aranthangi block with 332 ha of conversion. Avudayarkoil block experience maximum conversion of wetland to agriculture which is 2.25 ha shown Table. 02, Fig. 04 and Fig. 05.

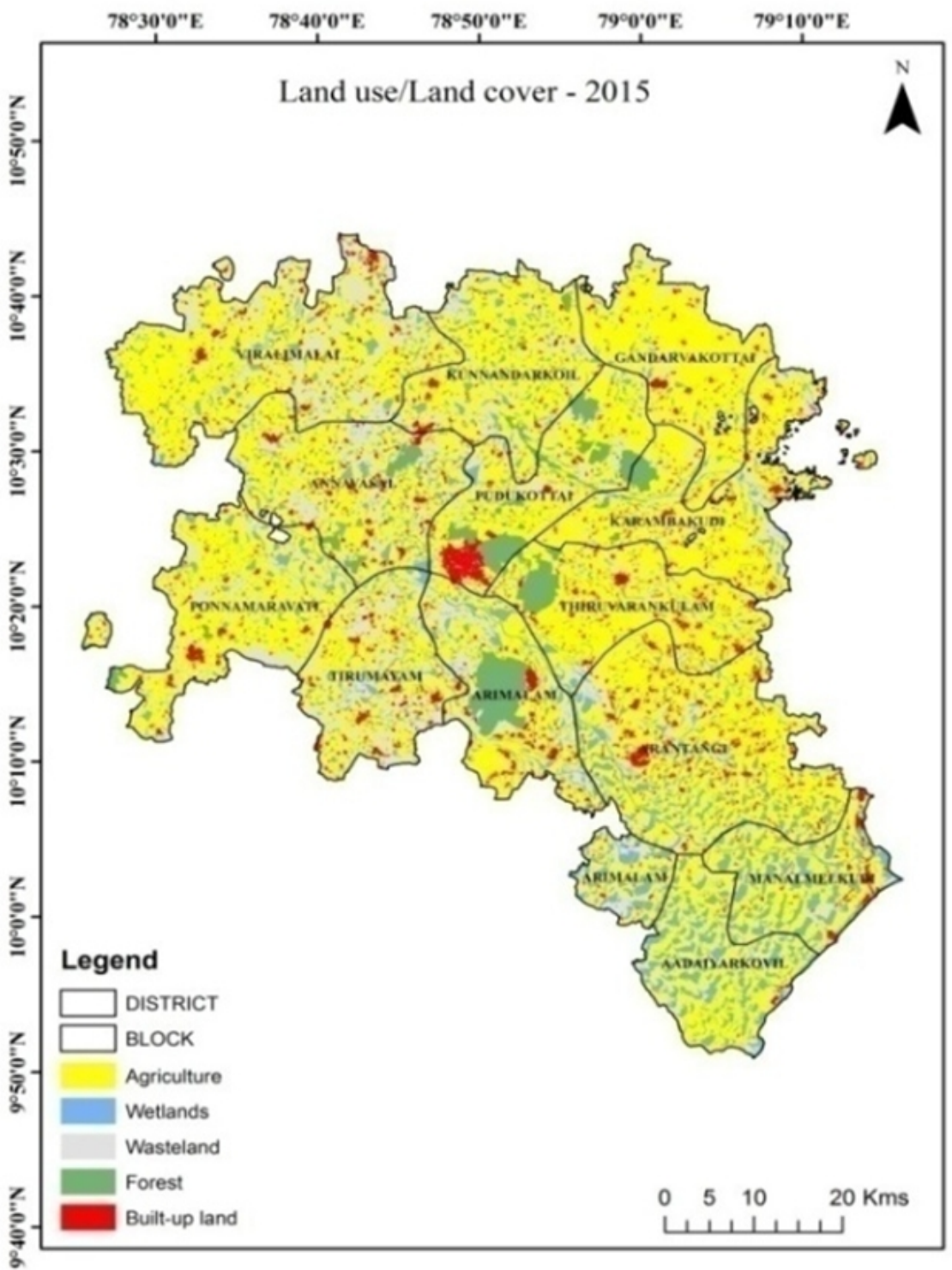

Figure 3. Land use/Land cover -2015 


\section{Techniques in Pudukkottai District of Tamil Nadu, India}

Table 2. Land use/Land cover change

Land use/Land cover change 2005 - 2010 (in $\mathrm{Ha}$ )

\begin{tabular}{|c|c|c|c|c|c|c|c|c|c|c|c|c|c|c|c|}
\hline \multicolumn{16}{|c|}{ Land use/Land cover change 2005 - 2010 (in Ha) } \\
\hline S. No & Land use conversion & 1 & 2 & 3 & 4 & 5 & 6 & 7 & 8 & 9 & 10 & 11 & 12 & 13 & 14 \\
\hline 1 & Agriculture To Built-up Land & 19.98 & 33.53 & 90.85 & 70.31 & 60.93 & 4.23 & 48.17 & 58.53 & 0.00 & 126.17 & 38.16 & 65.59 & 235.49 & 851.94 \\
\hline 2 & Agriculture To Waste Land & 219.29 & 653.98 & 522.20 & 505.11 & 206.45 & 148.27 & 216.50 & 0.00 & 56.03 & 212.77 & 73.60 & 2600.20 & 949.13 & 6363.54 \\
\hline 3 & Agriculture To Wet Lands & 62.86 & 0.00 & 0.00 & 104.00 & 0.00 & 22.46 & 0.00 & 1.15 & 30.98 & 0.00 & 0.00 & 0.21 & 4.48 & 226.13 \\
\hline 4 & Waste Land To Agriculture & 0.00 & 0.00 & 0.00 & 0.00 & 0.00 & 0.00 & 0.00 & 0.00 & 0.00 & 0.00 & 0.00 & 0.00 & 35.39 & 35.39 \\
\hline 5 & Wet Land To Agriculture & 3.98 & 0.00 & 0.00 & 0.00 & 0.00 & 0.00 & 0.00 & 37.84 & 0.00 & 0.00 & 0.00 & 0.00 & 23.62 & 65.44 \\
\hline \multicolumn{16}{|c|}{ Land use/Land cover change 2010-2015 (in $\mathrm{Ha}$ ) } \\
\hline 1 & Agriculture To Built-up Land & 4.46 & 198.01 & 173.17 & 95.91 & 66.77 & 219.26 & 79.24 & 60.21 & 328.76 & 410.15 & 127.31 & 143.21 & 369.86 & 2276.31 \\
\hline 2 & Agriculture To Waste Land & 510.37 & 5060.82 & 1720.76 & 3103.60 & 731.47 & 1580.60 & 2583.51 & 618.41 & 1755.47 & 2183.56 & 896.37 & 3671.91 & 7605.25 & 32022.11 \\
\hline 3 & Agriculture To Wet Lands & 91.48 & 0.00 & 0.00 & 22.36 & 0.00 & 0.00 & 0.00 & 12.53 & 40.30 & 69.87 & 17.84 & 119.49 & 10.17 & 384.04 \\
\hline 4 & Waste Land To Agriculture & 0.00 & 25.55 & 332.53 & 3.31 & 485.90 & 0.00 & 20.68 & 0.00 & 0.00 & 0.00 & 470.48 & 0.00 & 87.58 & 1426.04 \\
\hline 5 & Wet Land To Agriculture & 2.25 & 0.00 & 0.00 & 0.00 & 0.00 & 0.00 & 0.00 & 1.60 & 0.00 & 0.00 & 0.00 & 0.00 & 1.30 & 5.14 \\
\hline \multicolumn{16}{|c|}{ Land use/Land cover change 2005- 2015 (in $\mathrm{Ha}$ ) } \\
\hline 1 & Agriculture To Built-up Land & 19.98 & 231.54 & 264.02 & 166.22 & 127.70 & 223.49 & 127.40 & 118.74 & 328.76 & 536.32 & 165.46 & 243.95 & 605.35 & 3158.94 \\
\hline 2 & Agriculture To Waste Land & 729.66 & 5698.34 & 2242.96 & 3570.60 & 937.92 & 1728.87 & 2800.01 & 618.41 & 1811.50 & 2396.33 & 896.37 & 6236.97 & 8554.38 & 38222.33 \\
\hline 3 & Agriculture To Wet Lands & 154.34 & 0.00 & 0.00 & 164.48 & 0.00 & 22.46 & 0.00 & 13.68 & 71.28 & 69.87 & 17.84 & 119.70 & 14.64 & 648.29 \\
\hline 4 & Waste Land To Agriculture & 0.00 & 9.10 & 332.53 & 3.31 & 485.90 & 0.00 & 20.68 & 0.00 & 0.00 & 0.00 & 396.88 & 0.00 & 122.97 & 1371.37 \\
\hline \multirow[t]{2}{*}{5} & Wet Land To Agriculture & 6.23 & 0.00 & 0.00 & 0.00 & 0.00 & 0.00 & 0.00 & 39.44 & 0.00 & 0.00 & 0.00 & 0.00 & 24.92 & 70.59 \\
\hline & Total area & 25951.9 & 37207.27 & 54320.01 & 38732.84 & 30408.87 & 36711.64 & 33574.95 & 22740.03 & 37352.46 & 30381.55 & 32443.90 & 29460.95 & 55968.69 & 465255.0 \\
\hline
\end{tabular}

\section{Avudayarkoil}

Annavasal

Aranthangi

Arimalam

Gandharvakottai

Karambakudi
Manamelkudi

9 Ponnamaravathi

10 Pudukkottai

11 Thiruvarankulam

12 Thirumayam

13 Viralimalai

14 Total 
During the entire period from 2005 to 2015 approximately 42029 ha of agrarian land that is 3158 ha, 38222 ha and 648 ha has been converted built-up land, wasteland and wetland respectively. 1371 ha of wasteland and 70 ha of wetlands have converted to agriculture. Viralimalai block experience maximum of 605 ha has been converted to built-up land from agricultural land and minimum of 19 ha of agriculture land in Avudayarkoil block converted to built-up land. Again, in Viralimalai block maximum of 8554 ha of agrarian land converted to wasteland and minimum of 618 ha of agrarian land to wasteland. Arimalam block experience maximum of 164 ha of land converted to agrarian land from wetlands. Some blocks of Annavasal, Aranthangi, Gandharvakottai and Kunnandarkoil experienced no conversion of agricultural land to wetlands. Maximum of 485 ha of wasteland has converted in Gandharvakottai block to agricultural land but there is no conversion of wasteland to agriculture in Avudayarkoil, Karambakudi, Manamelkudi, ponnamaravathi, Pudukkottai and Thirumayam blocks. 39 ha of wetlands has converted to agricultural land in Manamelkudi block which is maximum as compared to other blocks shown in the Table. 02, Fig. 04 and Fig. 05.

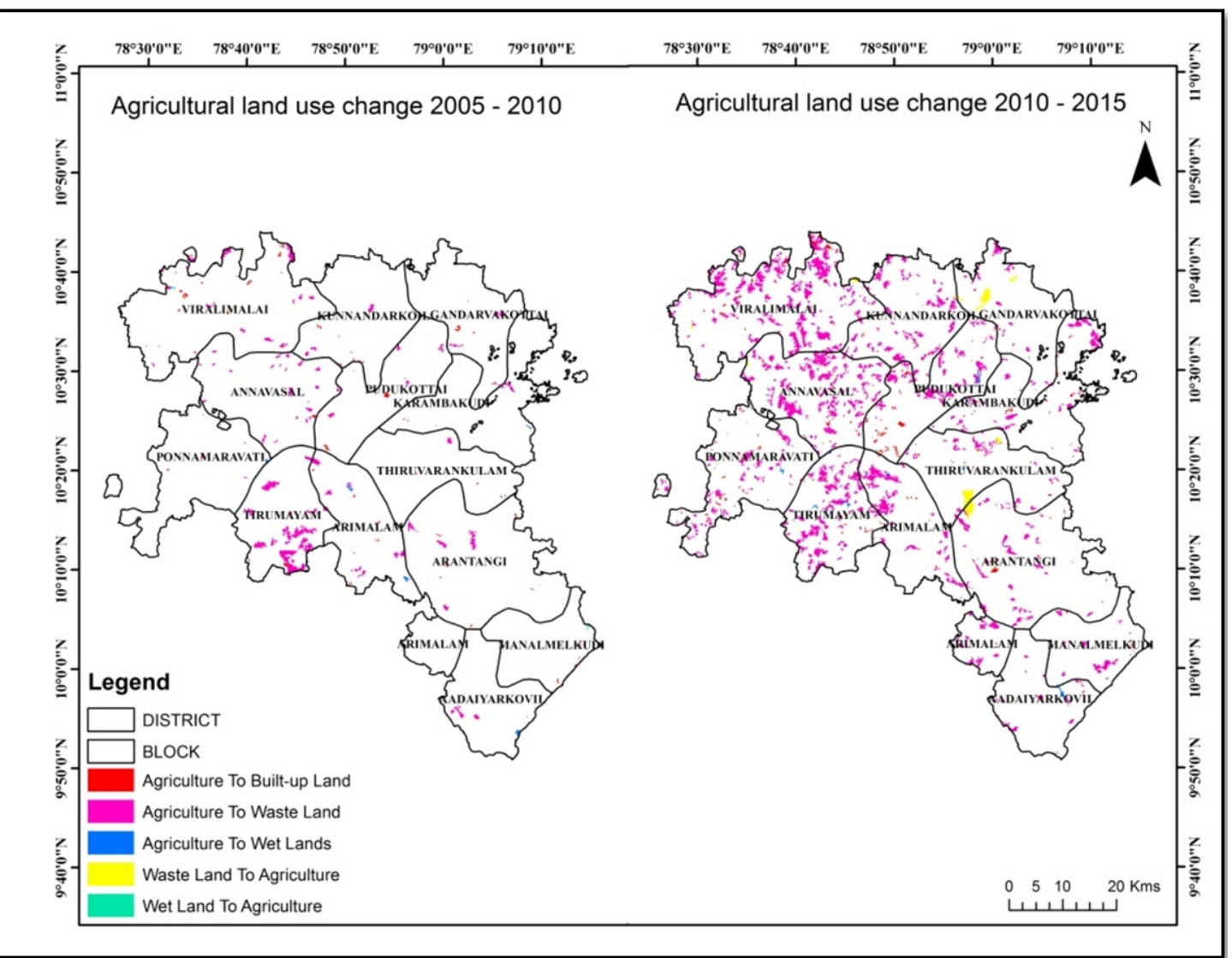

Figure 4. Agricultural land use change - (2005-2010 \& 2010 - 2015) 


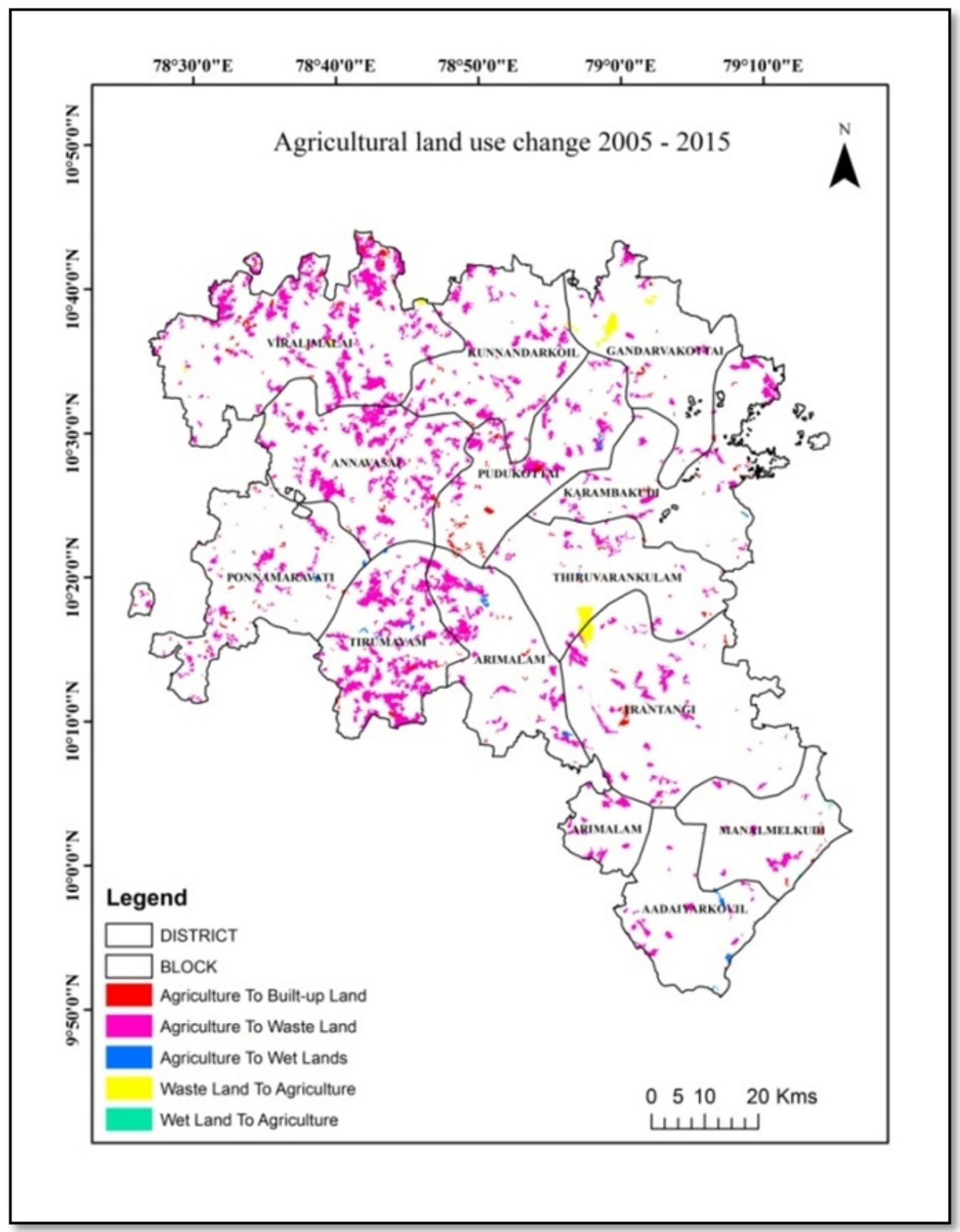

Figure 5. Agricultural land use change 2005 - 2015

\section{Net agricultural area loss}

Pudukkottai district experience high conversion of agricultural land to other land use/land cover and at the same time other land use/land cover change into agricultural land. Net agricultural land change can be found during the study period. Table 03 shows the block wise net agricultural land change in Pudukkottai district. Total net agricultural land conversion in Pudukkottai district is 7340 ha, 33251 ha and 40592 ha during the year $2005-2010,2010-2015$ and $2005-2015$ respectively.
Thirumayam block experience high net agricultural land conversion of 2666 ha followed by Viralimalai (1130 ha) and Annavasal block (687 ha). Minimum loss of agricultural land is in Manamelkudi with 21 ha during 2005 - 2010. During 2010 - 2015 maximum loss of agrarian land in Viralimalai block which is 7896 ha followed by Annavasal (5233 ha) and Thirumayam block (3934 ha). Minimum loss of agrarian land experienced in Gandharvakottai block with 312 ha shown in the Fig. 06. Overall from 2005 - 2015 Viralimalai block experience maximum loss of agrarian land which is 9026 ha followed 
by Thirumayam block (6600 ha), minimum loss is experience in Gandharvakottai block with 579 ha displayed in Fig. 06.

\section{Average annual agricultural loss}

This can be identified by dividing the value of net agricultural loss by the number of years has been taken for detection change. In this case, five years has been taken for initial two sets of changes and finally ten years has been taken for overall changes.

Table 3. Net agricultural area loss and average annual agricultural area loss

\begin{tabular}{|c|c|c|c|c|c|c|c|}
\hline \multirow{2}{*}{ S. No. } & \multirow{2}{*}{ Blocks } & \multicolumn{2}{|c|}{ Net agricultural area loss (in ha) } & \multicolumn{3}{c|}{ Average annual agricultural area loss (in ha) } \\
\cline { 3 - 8 } & & $2005-10$ & $2010-15$ & $2005-15$ & $2005-10$ & $2010-15$ & $2005-15$ \\
\hline 1 & Avudayarkoil & 298.15 & 604.07 & 902.21 & 59.63 & 120.81 & 89.78 \\
\hline 2 & Annavasal & 687.51 & 5233.28 & 5920.79 & 137.50 & 1046.66 & 592.08 \\
\hline 3 & Aranthangi & 613.05 & 1561.40 & 2174.45 & 122.61 & 312.28 & 217.44 \\
\hline 4 & Arimalam & 679.43 & 3218.57 & 3897.99 & 135.89 & 643.71 & 389.80 \\
\hline 5 & Gandharvakottai & 267.38 & 312.34 & 579.72 & 53.48 & 62.47 & 57.97 \\
\hline 6 & Karambakudi & 174.96 & 1799.86 & 1974.81 & 34.99 & 359.97 & 197.48 \\
\hline 7 & Kunnandarkoil & 264.67 & 2642.07 & 2906.73 & 52.93 & 528.41 & 290.67 \\
\hline 8 & Manamelkudi & 21.83 & 689.56 & 711.39 & 4.37 & 137.91 & 76.29 \\
\hline 9 & Ponnamaravathi & 87.01 & 2124.53 & 2211.55 & 17.40 & 424.91 & 221.15 \\
\hline 10 & Pudukkottai & 338.94 & 2663.58 & 3002.52 & 67.79 & 532.72 & 300.25 \\
\hline 11 & Thiruvarankulam & 111.76 & 571.03 & 682.79 & 22.35 & 114.21 & 68.28 \\
\hline 12 & Thirumayam & 2666.01 & 3934.62 & 6600.62 & 533.20 & 786.92 & 660.06 \\
\hline 13 & Viralimalai & 1130.09 & 7896.40 & 9026.48 & 226.02 & 1579.28 & 904.70 \\
\hline 14 & Grand Total & 7340.78 & 33251.28 & 40592.06 & 1468.16 & 6650.26 & 4065.97 \\
\hline
\end{tabular}

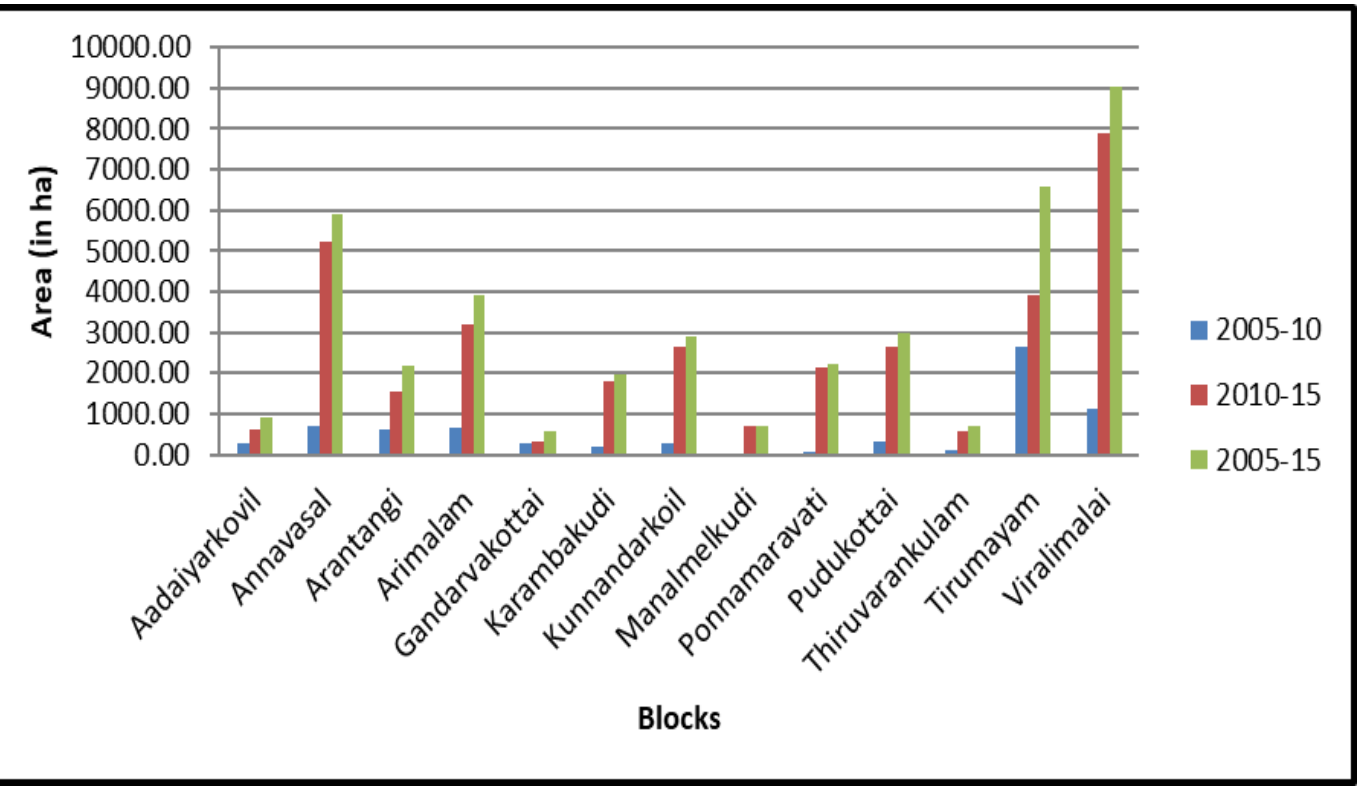

Figure 6. Net agricultural area loss 


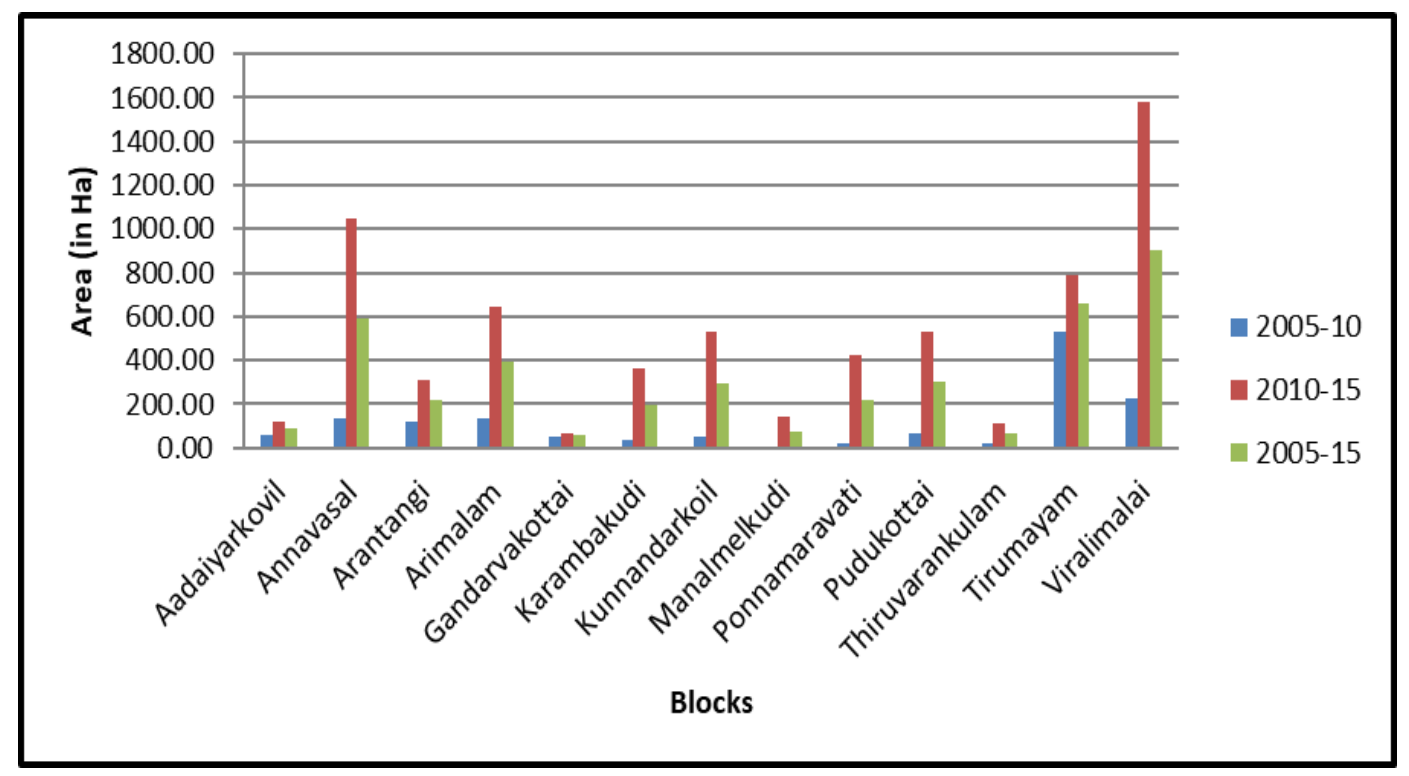

Figure 7. Average annual agricultural area loss

District average annual loss of agrarian land is 1468 ha per year, 6650 ha per year and 4065 ha per year during $2005-2010,2010-2015$ and $2005-2015$ respectively. Maximum average annual loss of agrarian land is in Thirumayam block which is 533 ha per year followed by Viralimalai block (226 ha per year). Manamelkudi block experiences low average annual agricultural loss which is only 4 ha per year. During 2010 to 2015 Viralimalai block experiences maximum average annual loss of agricultural land which is 1579 ha per year followed by Annavasal block which is 1046 ha per year. Minimum loss of average annual agricultural land is in Gandharvakottai block which is 62 ha per year given in the Table 03 and Fig. 07. During 2005 to 2015 viralimalai block has lost in agriculture land around 904 ha per year followed by Thirumayam block which is 660 ha per year. Low average annual agricultural loss happened in Gandharvakottai which accounts only 57 ha per year shown in Table 03 and Fig. 07.

\section{Annual rate of change of Agriculture}

Table 04 shows the annual rate of change of agriculture for the duration 2005 - 2010, $2010-2015$ and $2005-$ 2015. District annual rate of transit of agriculture for the duration $2005-2010,2010-2015$ and $2005-2015$ is $0.44 \%, 2.03 \%$ and $2.43 \%$ respectively. Maximum and minimum annual rate of change of agriculture is at Thirumayam block $(2.48 \%)$ and Manamelkudi block $(0.03 \%)$ respectively during $2005-2010$. Annual rate of transit of agriculture during the period $2010-2015$ is maximum in Thirumayam block with $4.18 \%$ and minimum at Gandharvakottai block with $0.24 \%$. The overall annual rate of transit of agriculture from 2005 2015 is maximum Thirumayam block (6.14\%) and minimum rate of change at Gandharvakottai block $(0.44 \%)$ shown in the Fig. 08. Block wise spatial distribution annual rate of transit of agricultural land is given in Fig 10.

\section{Dynamic degree}

Dynamic degree of agricultural land use changes for the year $2005-2010$ is maximum of $1.81 \%$ in Thirumayam block and minimum of $0.02 \%$ in Manamelkudi block. The District average dynamic degree for agricultural land use changes for the duration $2005-2010,2010-2015$ and $2005-2015$ is $0.31 \%, 1.42 \%$ and $0.87 \%$ respectively. Dynamic degree for agricultural land use is maximum in Viralimalai block which is $2.82 \%$ and minimum in Gandharvakottai which is $0.21 \%$ during the year 2010 2015. The overall dynamic degree for agricultural land use change from $2005-2015$ is maximum in Thirumayam block which is $2.24 \%$ and minimum in Gandharvakottai block which is $0.19 \%$. Block wise spatial distribution dynamic degree of agricultural land use is shown in Fig 10.

\section{Conclusions}

Maximum land use change of agricultural land has taken place during $2010-2015$ as compared to 2005 2010. Annual change of agricultural land is maximum in Thirumayam block during 2005 - 2010 and Viralimalai block during $2010-2015$. 
Table 4. Annual rates of change and Dynamic degree

\begin{tabular}{|c|c|c|c|c|c|c|c|}
\hline \multirow{2}{*}{ S. No } & \multirow{2}{*}{ Block name } & \multicolumn{3}{|c|}{ Annual rate of change } & \multicolumn{3}{c|}{ Dynamic Degree } \\
\cline { 3 - 8 } & & $2005-10$ & $2010-15$ & $2005-15$ & $2005-10$ & $2010-15$ & $2005-15$ \\
\hline 1 & Avudayarkoil & 0.37 & 0.77 & 1.12 & 0.23 & 0.47 & 0.35 \\
\hline 2 & Annavasal & 0.51 & 3.99 & 4.40 & 0.37 & 2.81 & 1.59 \\
\hline 3 & Aranthangi & 0.31 & 0.81 & 1.11 & 0.23 & 0.57 & 0.40 \\
\hline 4 & Arimalam & 0.60 & 2.94 & 3.45 & 0.35 & 1.66 & 1.01 \\
\hline 5 & Gandharvakottai & 0.21 & 0.24 & 0.44 & 0.18 & 0.21 & 0.19 \\
\hline 6 & Karambakudi & 0.12 & 1.25 & 1.37 & 0.10 & 0.98 & 0.54 \\
\hline 7 & Kunnandarkoil & 0.21 & 2.13 & 2.32 & 0.16 & 1.57 & 0.87 \\
\hline 8 & Manamelkudi & 0.03 & 1.02 & 1.13 & 0.02 & 0.61 & 0.34 \\
\hline 9 & Ponnamaravathi & 0.06 & 1.55 & 1.61 & 0.05 & 1.14 & 0.59 \\
\hline 10 & Pudukkottai & 0.34 & 2.71 & 3.00 & 0.22 & 1.75 & 0.99 \\
\hline 11 & Thiruvarankulam & 0.09 & 0.48 & 0.57 & 0.07 & 0.35 & 0.21 \\
\hline 12 & Thirumayam & 2.48 & 4.18 & 6.14 & 1.81 & 2.67 & 2.24 \\
\hline 13 & Viralimalai & 0.52 & 3.72 & 4.16 & 0.40 & 2.82 & 1.62 \\
\hline 14 & Grand Total & 0.44 & 2.03 & 2.43 & 0.32 & 1.43 & 0.87 \\
\hline
\end{tabular}

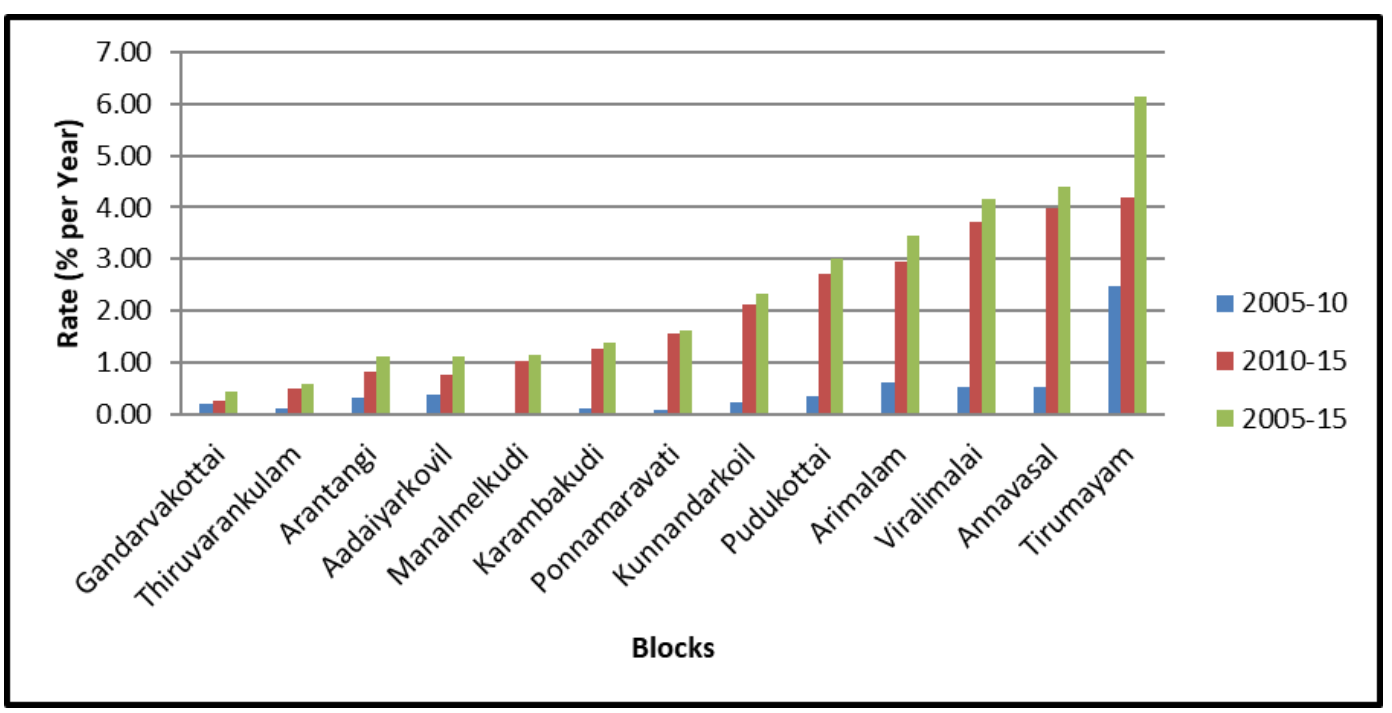

Figure 8. Annual rate of change of Agricultural land use

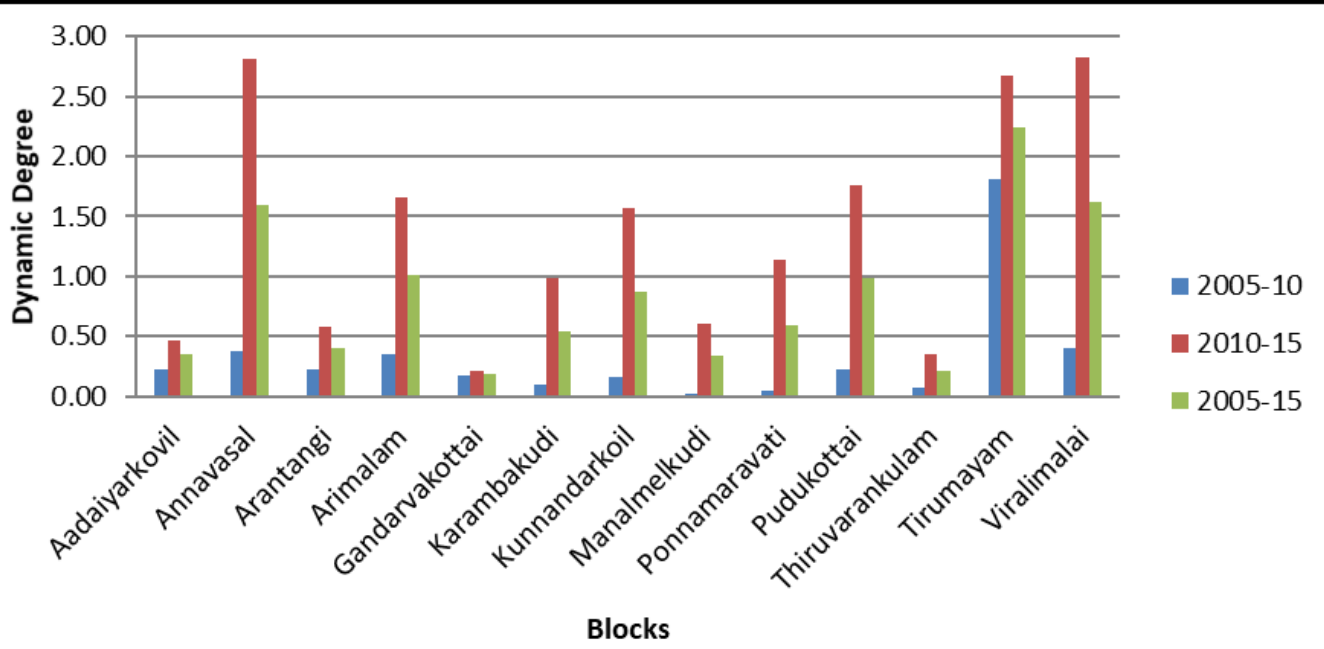

Figure 9. Dynamic degree of Agricultural land use 


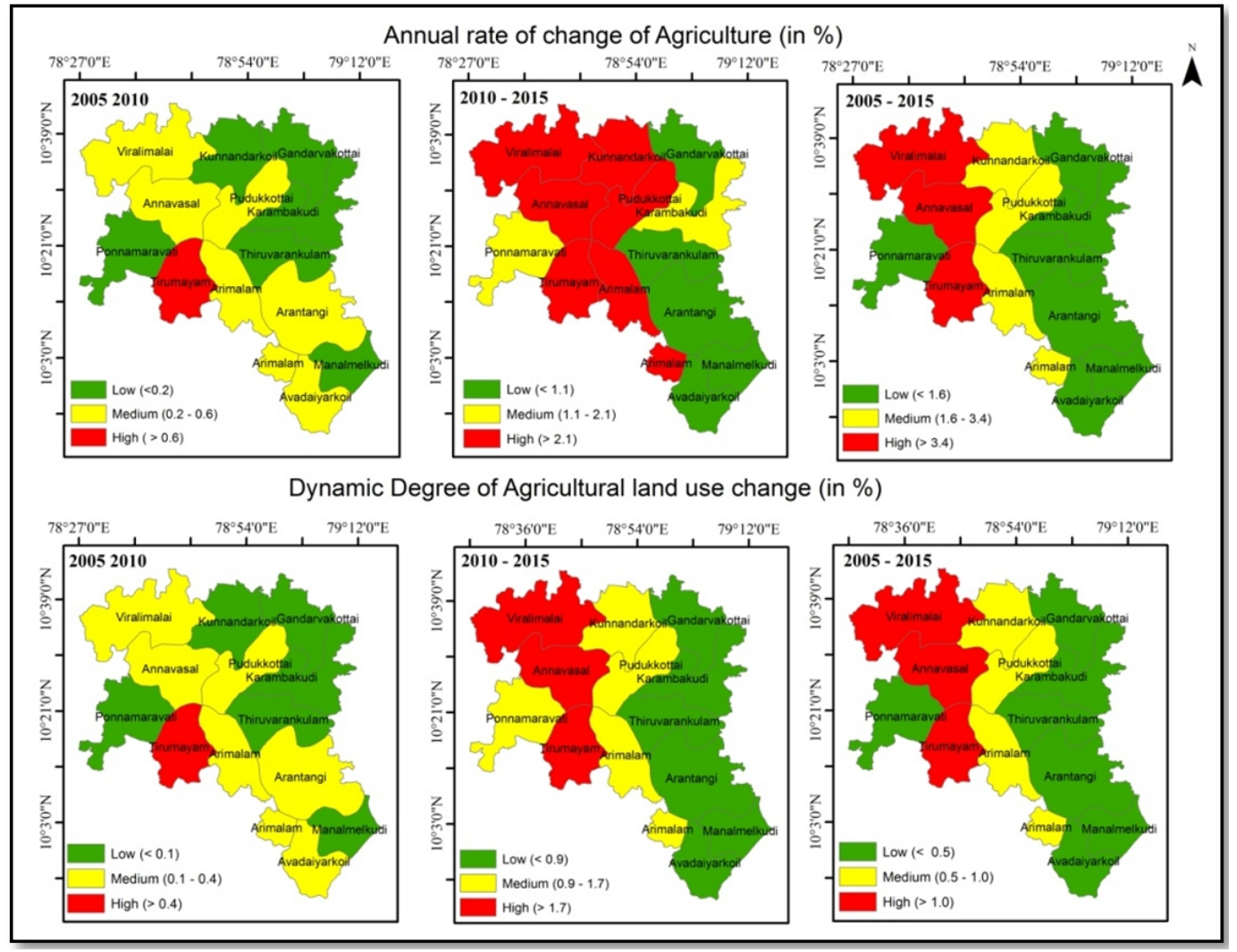

Figure 10. Block wise annual rate of change and Dynamic degree of Agricultural land use

Annual rate of change of agriculture is experiencing maximum in Thirumayam block during the study period but minimum annual rate of change of agriculture experience in Manamelkudi block during 2005-2010 and Gandharvakottai block in $2010-2015$. Dynamic degree of agricultural land use is maximum in Thirumayam block during 2005 - 2010 but during $2010-2015$ dynamic degree is maximum in Viralimalai block. The dynamic degree is maximum in Thirumayam block during 2005 2015 and minimum in Gandharvakottai block. Maximum of agricultural land has transformed into waste lands than built-up lands or wet lands during $2005-2010$ and $2010-$ 2015 . Nearly, $1.89 \%$ of the agricultural land has changed into wasteland during $2005-2010$ but only $0.25 \%$ and $0.04 \%$ of the agricultural land has changed into built-up land and wet land respectively. Almost $9.35 \%$ of agricultural land changed into wasteland during $2010-$ 2015 but only $0.69 \%$ and $0.11 \%$ of the agricultural land has changed into built-up land and wetland respectively. The study has concluded that agriculture land changed into other land uses which will significantly impact on the human as well as Indian economic because agriculture is the backbone of Indian economy. This become particularly in India which is considered as The Geographical Information system is extremely useful for analyzing land use/land cover and changes to observe and mitigate the extremity.

\section{REFERENCES}

[1] Bisht, B. S., and B. P. Kothyari. "Land-cover change analysis of Garur Ganga watershed using GIS/remote sensing technique." Journal of the Indian Society of Remote Sensing 29.3 (2001): 137-141.

[2] Dhinwa, P. S., et al. "Land use change analysis of Bharatpur district using GIS." Journal of the Indian society of Remote Sensing 20.4 (1992): 237-250.

[3] Fonji, S. F., \& Taff, G. N. (2014). Using satellite data to monitor land-use land-cover change in North-eastern Latvia. Springerplus, 3(1), 61.

[4] Jensen JR (2005) Introductory Digital Image Processing: A Remote Sensing Perspective. Pearson Education, Inc., New Jersey.

[5] Kuang, Wenhui, et al. "The rapid and massive urban and industrial land expansions in China between 1990 and 2010: A CLUD-based analysis of their trajectories, patterns, and drivers." Landscape and Urban Planning 145 (2016): 21-33.

[6] Lambin, Eric F., and Helmut J. Geist, eds. Land-use and land-cover change: local processes and global impacts. Springer Science \& Business Media, 2008.

[7] Lambin, Eric F., Helmut J. Geist, and Erika Lepers. "Dynamics of land-use and land-cover change in tropical regions." Annual review of environment and resources 28.1 (2003): 205-241.

[8] Latham, Marc, and Bernard Denis. "The study of land 
potential: an open-ended inquiry." (1980): 113-123.

[9] Lawler, Joshua J., et al. "Projected land-use change impacts on ecosystem services in the United States." Proceedings of the National Academy of Sciences (2014): 201405557.

[10] Lillesand, Thomas M., and Ralph W. Kiefer. "Remote sensing and photo interpretation." John Wiley and Sons: New York (1994): 750.

[11] Mooney, Harold A., Anantha Duraiappah, and Anne Larigauderie. "Evolution of natural and social science interactions in global change research programs." Proceedings of the National Academy of Sciences 110.Suppl ement 1 (2013): 3665-3672.

[12] National Remote Sensing Agency (NRSA) (1989). Manual of Nationwide landuse/landcover mapping using satellite imagery, Part-I, A National Remote Sensing Agency, Hyderabad publication of 1989.

[13] Ning, Jia, et al. "Spatiotemporal patterns and characteristics of land-use change in China during 2010-2015." Journal of Geographical Sciences 28.5 (2018): 547-562.
[14] Pflugmacher, Dirk, Warren B. Cohen, and Robert E. Kennedy. "Using Landsat-derived disturbance history (1972-2010) to predict current forest structure." Remote Sensing of Environment 122 (2012): 146-165.

[15] Steffen, Will, et al. Global change and the earth system: a planet under pressure. Springer Science \& Business Media, 2006.

[16] Wang, Jing, et al. "Land-use changes and policy dimension driving forces in China: Present, trend and future." Land use policy 29.4 (2012): 737-749.

[17] Wulder, Michael A., et al. "Landsat continuity: Issues and opportunities for land cover monitoring." Remote Sensing of Environment 112.3 (2008): 955-969.

[18] Young, Anthony. Land resources: now and for the future. Cambridge University Press, 2000.

[19] Zhu, Z., \& Woodcock, C. E. (2014). Continuous change detection and classification of land cover using all available Landsat data. Remote sensing of Environment, 144, 152-171. 